\title{
SIMULACRO DE ARGUMENTAÇÃO: O MEME COMO NEUTRALIZADOR DE CONFLITO NO TWITTER \author{
NEUTRALIZER IN TWITTER
} \\ ARGUMENT SIMULACRUM: MEME AS A CONFLICT
}

\author{
Luíza Álvares Dias ${ }^{1}$ \\ Rubens Damasceno-Morais ${ }^{2}$
}

\begin{abstract}
RESUMO: Em 2018, a polarização fez com que as redes sociais se tornassem palco de discussões/dissensões a respeito da política do país. Apesar disso, o mundo virtual possibilita a troca e exposição de opiniões. Em alguns conflitos, observou-se o uso do humor para amenizar ou inflar o desacordo. Neste artigo, extraímos um diálogo da rede social Twitter em que o humor está materializado em um meme, material imagético ou audiovisual que possui conteúdo humorístico e se caracteriza por se tornar "viral", compartilhado rapidamente pelo maior número de pessoas na internet. Dessa forma, o objetivo desta pesquisa qualitativa foi analisar a função do meme neste episódio. Para isso, utilizamos o modelo dialogal de Plantin (2016), em que a interação é primordial para a existência de um conflito/estase. Com isso, verificamos a presença da estase, cuja progressão foi balizada pelo conteúdo do meme. Apoiados em Bergson (1983), percebemos que o humor pode ser um eficiente recurso retórico em contexto político, neste caso, para intimidar o interlocutor (SANTOS JUNIOR, 2017). A utilização do meme como forma de impedir a progressão da argumentação nos faz pensar que, em vez de espaço para (des)construir ideias, as redes sociais estão se tornando ringues de luta virtuais.
\end{abstract}

PALAVRAS-CHAVE: Modelo dialogal. Meme. Conflito. Redes sociais. Estase.

\begin{abstract}
In 2018, political polarization made social networks a stage for discussions/dissensions regarding Brazil's politics. Despite this, the virtual world allows the exchange and exposure of opinions. In some conflicts, we observed the use of humor to alleviate or inflate disagreement. In this article, we extract a dialogue from the social network Twitter in which the humor was materialized in a meme, imagery or audiovisual material that has humorous content and is characterized by becoming "viral", quickly shared by the largest number of people on the internet. Thus, the objective of this qualitative research was to analyze the function of the meme in this episode. For that, we used the dialogical model of Plantin (2016), in which the interaction is essential for the existence of a conflict/stasis. With that, we verified the presence of stasis, but the meme content blocked the argumentation progress. Supported by Bergson (1983), we realized that humor could be an efficient rhetorical resource in a political context, in this case, to intimidate (SANTOS JUNIOR, 2017). The use of the meme as a way to prevent the
\end{abstract}

\footnotetext{
${ }^{1}$ Graduanda em Letras: Português na Universidade Federal de Goiás (UFG). E-mail: luiza.dias@discente.ufg.br

${ }^{2}$ Professor doutor na Universidade Federal de Goiás (UFG). Coordenador do grupo de estudos Teorias da Argumentação e Retórica/TEAR (CNPq). E-mail: damasceno.morais@ufg.br
} 
argument progression makes us think that, instead of space to (de)construct ideas, social networks are becoming virtual fighting rings.

KEYWORDS: Dialogical model. Meme. Conflict. Argumentation. Social media. Stasis.

\section{Introdução}

No contexto das eleições de 2018, a polarização política marcou decisivamente o Brasil, já que na eleição para a presidência naquele ano afloraram intensas discordâncias entre polos ideologicamente antagônicos. Enquanto a esquerda era representada pelo candidato Fernando Haddad, do Partido dos Trabalhadores (PT), a direita foi representada pelo candidato Jair Bolsonaro, do Partido Social Liberal (PSL). E, à medida que cada candidato tentava angariar eleitores, as redes sociais se tornaram palco de violentos ataques acerca do panorama político.

As redes sociais, nesse sentido, mobilizaram não apenas discussões verbais, mas o uso exagerado de imagens, com a utilização, principalmente, de memes. Considerando a importância da internet para a exposição e compartilhamento de ideias e destacando o uso do gênero meme, visto de forma recorrente nas interações virtuais de âmbito político, este artigo se incumbiu de problematizar a utilização de memes nas interações em redes sociais.

Para estudar os meios virtuais, torna-se imprescindível compreender suas características singulares. As respostas podem não ser imediatas como em conversas facea-face; no entanto, os usuários podem utilizar elementos externos, como sites de pesquisa, links, imagens, vídeos, áudios e GIFs. E como são, muitas vezes, encobertas pelo anonimato e distância de seus interlocutores, as pessoas utilizam tal fato ao seu favor para propagar notícias falsas, criar perfis falsos e, até mesmo, ridicularizar outras pessoas (GONÇALVES, 2019; FERREIRA, VASCONCELOS, 2019).

Consequentemente, a internet é palco para polêmicas, não no sentido negativo da palavra, mas na perspectiva de Amossy (2017), que vê a polêmica em sua função social, de confronto público de ideias à constituição de comunidades de protesto para agir em prol de algo. Porém, nem sempre a internet concentra pessoas dispostas a discutir de maneira respeitosa pelas razões propostas acima e, além disso, endossam ainda mais as discussões com piadas e brincadeiras, tal como acontece na utilização dos memes, um dos recursos utilizados cada vez com mais frequência nesse meio. 
Pensando nisso, o objetivo deste artigo foi analisar o papel do meme na interação argumentativa, a partir do modelo dialogal da argumentação. Sendo assim, analisamos, em específico, um "episódio argumentativo" - situação interativa em que se pode verificar um conflito entre posicionamentos (PLANTIN, 2016) - em uma rede social, isto é, uma situação interativa em que se pode perceber um conflito entre posicionamentos de diferentes atores. Para verificar a construção da argumentação a partir do meme, foi analisada a existência (ou inexistência) da estase, do conflito, termo caro ao modelo dialogal, que embasou nossa análise.

A importância deste artigo, portanto, advém do fato de que a argumentação nas redes sociais está se deslocando para segundo, até terceiro plano, visto que as pessoas, inseridas em um contexto em que visões de mundo aparentemente opostas estão em constante conflito, estão mais voltadas para atacarem umas às outras, sem se preocuparem em (contra)argumentar. Nesse universo, lacrar é o que gera likes, e ponto final. Assim, as redes sociais, em vez de se tornarem palco para que pessoas tenham acesso a opiniões diferentes e possam sobre elas refletir e as aceitar ou refutar, estão se tornando um ringue virtual $^{3}$. Com isso, esperamos contribuir para os estudos argumentativos em redes sociais, revisando e ampliando a bibliografia especializada acerca de estudos da argumentação e retórica ao trabalharmos com o modelo dialogal da argumentação, inédito em pesquisas no Brasil.

\section{Memes: o humor na internet}

Os memes possuem formas variadas, podendo apresentar-se como fotos, vídeos, imagens diversas ou uma mera frase, em que a única condição específica é "viralizar", isto é, ser compartilhado pelo maior número de pessoas e ter grande repercussão nas redes sociais. O termo foi utilizado inicialmente por Richard Dawkins, em 1976, para designar outra unidade capaz de replicação além dos genes, nossos conhecidos amigos do universo da Biologia. Segundo esse autor os memes são replicadores culturais da humanidade, uma unidade de transmissão cultural, de imitação (DAWKINS, 2017). Não se sabe exatamente

\footnotetext{
${ }^{3}$ Pensamos aqui no caso da estudante Mayara Petruso, a qual, após uma série de comentários desrespeitosos dirigidos a nordestinos, devido à eleição de Dilma Rousseff em 2010, ela recebeu mensagens violentas e ameaças em sua timeline. A repercussão levou a jovem a perder o emprego e a se mudar de cidade e de faculdade. Apesar de ter sido condenada judicialmente por seus comentários - o que achamos justo - ela foi linchada virtualmente $\quad$ o que achamos perigoso. Disponível em: https://www.correio24horas.com.br/noticia/nid/justica-condena-estudante-mayara-petruso-porpreconceito-contra-nordestinos/. Acesso em: 6 maio 2020.
} 
quando o termo migrou para o meio digital, contudo o nome é pertinente, pois os memes são, de certa forma, transmissores culturais. O material que se torna viral está ligado ao que determinada sociedade considera divertido ou interessante. No Brasil, é muito comum a repercussão de vídeos considerados engraçados nas redes, tal como o vídeo do cão Chico, gravado por sua dona que, ao chegar em casa, depara-se com o seu colchão totalmente destruído pelo animal de estimação ${ }^{4}$. Após ser compartilhado por milhares de pessoas, a dona ganhou um novo colchão, assim como o Chico.

Os memes, assim, costumam cumprir uma função social de engajamento, algumas vezes resultando em consequências - negativas ou positivas - caso a imagem de uma pessoa ou até mesmo a de um pet se torne viral. A relevância do meme para o ambiente virtual, portanto, leva-nos a pensar nos gêneros textuais que surgiram - e os em ascensão - desde o surgimento e popularização da internet, como o e-mail, as mensagens de texto, os chats, os fóruns e, mais recentemente, os próprios memes. Marcuschi (2008) destaca que a noção de gênero não é exclusiva da literatura, podendo ser considerada qualquer categoria de discurso, oral ou escrita, independentemente de ter ou não pretensão literária. O que determina um gênero é a função, não a forma, uma vez que "[...] cada gênero textual tem um propósito bastante claro que o determina e lhe dá uma esfera de circulação" (MARCUSCHI, 2008, p. 150). Contudo é importante que não os concebamos como estruturas rígidas, já que inseridos na interação social e, consequentemente, entremeados pela linguagem, possuem formas fluidas, que se modificam de acordo com a intencionalidade do interlocutor.

Dessa forma, evidencia-se o meme como gênero textual, pertencente às redes sociais. Frequentemente os memes são utilizados em interações virtuais, tendo sido observado seu uso de forma recorrente nas discussões a respeito das eleições à presidência em 2018. Observando essa utilização pelos usuários, pensamos na possibilidade de considerar o meme, além de um gênero textual, como um recurso argumentativo, como tentaremos demostrar na análise que segue, a partir do modelo dialogal da argumentação.

\section{As significações e problemáticas do cômico}

\footnotetext{
4 Disponível em: <https://www.otempo.com.br/interessa/bizarrices/voce-conhece-o-chico-cachorrodestroi-cama-e-video-viraliza-veja-1.2211442>. Acesso em: 12 jan. 2020.
} 
A comicidade ${ }^{5}$ não é uma propriedade exclusivamente retórica e argumentativa. Com efeito, segundo Bergson, "não há comicidade fora do que é propriamente humano", já que o homem é definido como o único “animal que ri” (1983, p. 7). O filósofo aponta características para algo ser considerado humorístico, entre elas, o aspecto de coletividade. O riso necessita de eco porque, segundo ele, é necessário que outras pessoas também riam. Bergson (1983) também aponta a função social do cômico: a humilhação. O riso, assim, serviria para humilhar quem é atingido por uma troça e não deixa de ser uma punição social, pois, mesmo se for leve, é temida, embora, muitas vezes, no universo da "lacração", as pessoas não se importem muito em serem "humilhadas" desde que sejam lembradas, mesmo que de forma ridícula, a partir de um meme ou afim. Mas essa já é uma outra questão que não cabe discutir neste artigo.

Além disso, o riso não é sempre justo e nem sempre bom. Além de humilhar, ele intimida e pode ser utilizado como um recurso político. Por exemplo, fazer com que o opositor seja motivo de riso, atraindo pessoas com a mesma opinião, fazer caricaturas, charges ou até mesmo sintetizar ideias complexas em algo humorístico. É possível conhecer uma pessoa a partir do que ela ri - ou até mesmo com quem. Reconhecemos o fato de que a sensibilidade não gera o riso, e sim a insensibilidade, por isso "o riso seria, no fundo, uma questão de perspectiva, demonstrando o quão sensível ou insensível somos, ou estamos, em relação ao objeto que motivou a risada." (SANTOS JUNIOR, 2017, p. 220).

Quanto às posições que ocupam os algozes e os humilhados, Santos Junior (2017), a partir dos ensinamentos de retórica de Cícero e Quintiliano, elucida o aspecto sempre hierárquico no qual as partes envolvidas em uma argumentação se encontram no momento em que o humor é trazido à tona. Há os superiores (aqueles que humilham) e os inferiores (de quem se ri). Portanto, o humor não se apresenta com a ingenuidade que talvez o senso comum lhe parece impor. Na realidade, está inserido em um sistema de poder, com mecanismos particulares.

Enquanto Bergson (1983) e Santos Junior (2017) enxergam os aspectos sociológicos e filosóficos do humor, Luiz Carlos Travaglia (1990) analisa o tema por

\footnotetext{
5 Tendo em vista que para Bergson o cômico e o riso emergem a partir do convívio social, é justamente por isso que sua efetividade depende do contexto que delimita do que se pode ou não rir, o que é e o que não é engraçado, assim como ocorre com os memes. Tratamos nessa pesquisa termos como cômico e humor como equivalentes, baseando-nos, grosso modo, na perspectiva de tal teórico. Dado o exíguo espaço deste artigo, não temos como problematizar tais matizes conceituais.
} 
meio da Linguística. Nesse sentido, as duas áreas no bojo dos estudos linguísticos que podem contribuir bastante para o estudo do humor são a semântica e a pragmática, "lidando com conceitos tais como pressuposições, implicações e implicaturas, atos de fala, inferências, estratégias conversacionais, mundos possíveis, etc.” (TRAVAGLIA, 1990, p. 61).

Segundo Raskin (1987 apud TRAVAGLIA, 1990), o pesquisador deve observar o humor verbal como um texto para, assim, descobrir um conjunto de características linguísticas intrínsecas ao texto humorístico. Já para Travaglia (1990), textos humorísticos podem ter características particulares, mas é importante que um pesquisador se atenha ao fato de que há características exteriores ao texto, como o contexto sóciohistórico e cultural, que também o permeiam. De acordo com o linguista, “[...] cada povo, cada conjunto sociocultural tem características só suas e, como o humor depende da situação como um todo, o seu conteúdo difere de sociedade para sociedade e de um período histórico para outro.” (1990, p. 70-71). E, para que haja compreensão do receptor do conteúdo humorístico, humorista e audiência devem estar em consonância, para que o humor seja recebido como humor, e não como pena ou revolta.

Por conta disso, o humor, notadamente o humor político, pode ser mal interpretado, considerando-se que sem o conhecimento do contexto no qual a questão humorística se sustenta, o auditório para quem o discurso é dirigido (GRÁCIO, 2013) pode não o entender. Isso pode acontecer em qualquer contexto, no entanto, no âmbito político as consequências de um desentendimento podem ser mais graves, ainda mais para quem realiza a piada.

Dessa forma, o humor político possui tanto um lado sério quanto propriamente humorístico. Enquanto o sério está relacionado à informação prévia que uma pessoa precisa para entender a comicidade, o humor é o elemento necessário para que a "piada" não seja levada totalmente a sério, ancorada firmemente à realidade (TSAKONA; POPA, 2011), já que:

No plano linguístico $(\log o s)$, podemos dizer que humor ocupa uma faceta do lado patológico da linguagem verbal, tendo em vista que quebra as barreiras do que é considerado 'normal' ou 'sério', ou seja, por meio do humor, é possível dizer certas coisas que fora dele seriam impraticáveis. (CARMELINO, 2012, p.48).

Tendo em vista esse aspecto dual, de seriedade e comicidade, o humor ainda possui a faceta de denunciar, manter o equilíbrio social e psicológico, demonstrar outras 
possibilidades de visão de mundo e valores, desmontando uma realidade aparentemente sólida (TRAVAGLIA, 1990). Por conta disso, pode ser utilizado como arma de dominação, apontando estereótipos de determinado grupo, por exemplo, e taxando-os como "engraçado". Por outro lado, quando se trata de reagir a uma opressão, esse grupo pode inverter a situação, ridicularizando o opressor (TRAVAGLIA, 1990). Dessa forma, além dos aspectos de informar, gerar reflexões, ser utilizado como recurso de dominação, o humor - mais especificamente, o humor político - é uma forma de resistência a opressões políticas e injustiças sociais (TSAKONA; POPA, 2011).

\section{O modelo dialogal e a estase}

A argumentação, como área de pesquisa, é vasta e teorizada desde a Antiguidade. Cada vertente possui suas definições para os termos argumentação e argumento. $\mathrm{O}$ modelo dialogal, teorizado por Plantin (2016), entende a argumentação como interação problematizante orientada por uma questão. Além disso, um argumento leva, necessariamente, a uma conclusão. O modelo dialogal conversa abertamente com a retórica e com a dialética. Esta é a arte do "bem dialogar" e implica a descoberta de contradições na fala para desenvolver o conhecimento; aquela, isto é, a retórica, a arte do "bem falar", que possui a intenção de persuadir. Com isso, o modelo dialogal se nutriu de algumas ideias dessas duas abordagens para se desenvolver.

A Retórica ofereceu as noções de orador, interlocutor e contraditor. Respectivamente, "aquele que deve persuadir" $\rightarrow$ "aquele que deve ser persuadido" $\rightarrow$ “o que deverá ser contestado.” (DAMASCENO-MORAIS, 2020, p. 150). A partir disso, o modelo dialogal (PLANTIN, 2016) formula os papéis de atuação: Proponente, Oponente e Terceiro. O Proponente incita a argumentação, o Oponente se opõe ao argumento e ao Terceiro cabe a dúvida, pois é ele quem estimula o conflito, denominado estase nessa perspectiva teórica.

A dialética também possui as noções de proponente e oponente, em que um é o indagador (proponente) e o outro responde às questões (oponente). No entanto, a perspectiva dialogal se distancia da dialética clássica e se aproxima da dialética conversacional ao focar no diálogo, pois, nesta abordagem, a argumentação atua como espaço de negociação, sendo assim, são os interlocutores que irão moderar a interação, não havendo regras pré-definidas (DAMASCENO-MORAIS, 2019). Dessa forma, sem o caráter normativo, a lógica dialogal possui um campo maior para análise, visto que 
examina o peso dos argumentos nas interações. Observa-se, ainda, o dialogismo (interdiscursivo) e as diferentes visões, pontos de vista, entre aqueles que constituem a interação, via papéis de atuação.

O modelo dialogal, no entanto, não focaliza o dialogismo em si, tampouco o raciocínio empregado na argumentação. O pressuposto é o surgimento de uma questão. Ao surgir uma dúvida, surge, consequentemente, uma questão argumentativa - oposição de dois pontos de vista, ligados a diferentes doxai (valores). Em seguida, surge a estase, o conflito destes posicionamentos contrários.

Grácio (2013, p. 122) define estase como "um choque de discursos e o problema ou as questões que levanta estarão na base da especificação das exigências segundo as quais se poderão tematizar e desenvolver os argumentos apropriados", ou melhor, a partir do conflito, da divergência de ideias entre as partes, serão construídos determinados argumentos para solvê-lo ou não. A perspectiva dialogal, diferentemente da erística, normalmente não implica a ideia de um ganhador ou perdedor, pois, para Plantin (2016), é necessário haver cooperação ao argumentar.

Outro ponto importante a ser ressaltado é a diferença entre questão argumentativa e estase. Plantin (2016) define a questão argumentativa como a corporificação do discurso dissonante a partir da divergência entre pontos de vista. Dessa forma, utilizando uma analogia, a questão argumentativa seria a pequena chama que daria origem ao incêndio a estase propriamente dita. Assim, a estase - o momento do conflito entre pontos de vista opostos - só surge a partir da questão, embora ambos termos indiquem dissenso.

\section{Constituição da teia interacional no ambiente virtual $T$ witter}

Com o intuito de mostrar como ocorre a repercussão e o diálogo no Twitter, é fundamental explicar e esquematizar a relação dialogal entre internautas para melhor entendimento da análise que propomos à frente. Nesta rede social, a interação por comentários é sequencial, ou seja, uma resposta sucede a outra, como se fossem turnos de fala. A repercussão de uma publicação, chamada de tweet no Twitter, é medida pelo número de likes (o ato de "favoritar" uma postagem) e pelo número de retweets, número 
de perfis que compartilharam a publicação. Na postagem que gerou a discussão que aqui escolhemos para análise, o número de likes e de retweets foi alto ${ }^{6}$.

Na primeira captura de tela (imagem 1), temos uma compilação de vídeos do candidato Jair Bolsonaro (PSL), proferindo falas polêmicas em diversas entrevistas e vídeos. Em contrapartida, o vídeo apresenta uma entrevista feita para a TV Record, à época das eleições, em que ele diz não se lembrar dos discursos polêmicos que enunciou no passado, além de pedir provas de que os proferiu. Na legenda, o usuário escreve: "não sei vocês, mas eu não votaria em um candidato que não lembra nem do que fala".

Imagem 1: excerto de uma publicação no Twitter

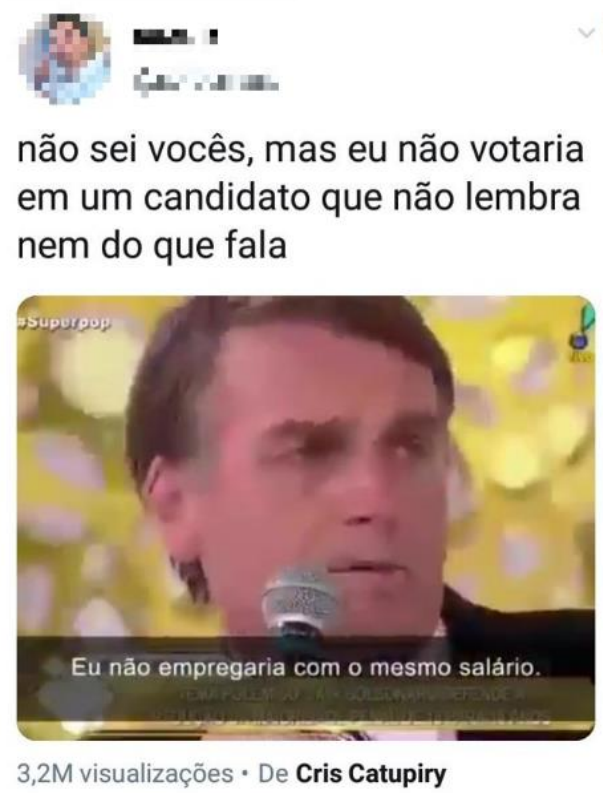

Fonte: printscreen da rede social Twitter

A publicação teve muitas interações (como dito, não foi possível capturar essa informação no printscreen) e, entre os comentários, foram selecionadas algumas respostas (imagens 2 e 3). Nota-se que, a seguir, os usuários, os participantes da interação, serão chamados de interactantes ${ }^{7}$.

\footnotetext{
${ }^{6}$ Infelizmente, pela captura de tela feita, não é possível visualizar esses dados - a captura, devido ao tamanho da tela do celular, cortou esses dados da primeira publicação (imagem 1). Além disso, a interação também pôde ser averiguada a partir do número de comentários, infelizmente também ausente na captura de tela.

${ }^{7}$ Mesmo sendo uma rede social pública com dados de domínio público, esta pesquisa não foi submetida ao Comitê de Ética, visto que seria impossível pedir autorização de divulgação a cada autor/a de cada comentário, visto que muitos perfis são fakes ou meramente baseados em pseudônimos e, por isso, de
} 
Imagem 2: primeira resposta à publicação

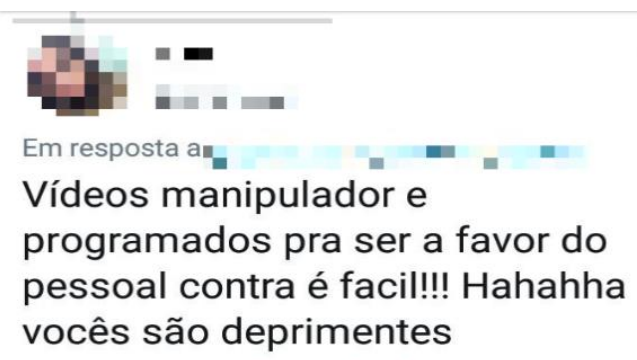

16:58 $\cdot 06$ out $18 \cdot$ Twitter for iPhone

Fonte: printscreen da rede social Twitter

No comentário, o usuário (interactante 2) afirma que os vídeos nos quais o político aparece foram manipulados para que as pessoas contra o candidato à presidência de Jair Bolsonaro pudessem ter argumentos contra ele. Em seguida, o usuário da primeira postagem (interactante 1), que contém o vídeo, replica (imagem 3):

Imagem 3: primeira utilização do Bingonario

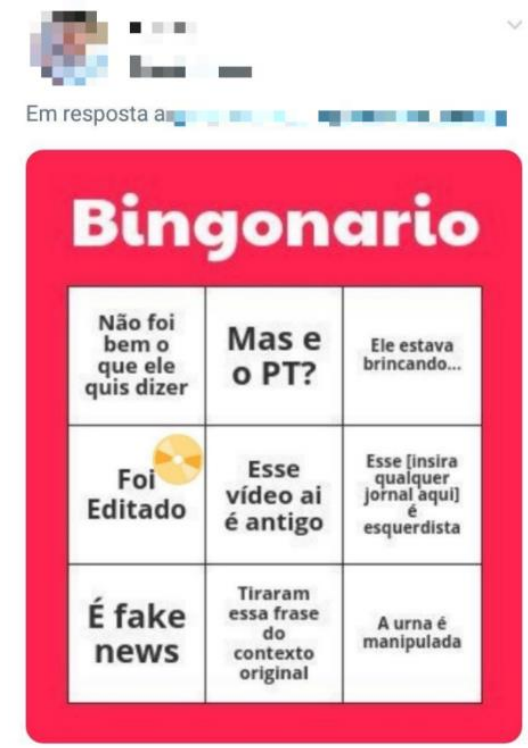

Fonte: printscreen da rede social Twitter.

A imagem 3 representa o meme a partir do qual proporemos a análise pormenorizada na próxima seção. A condição primeira para um material se tornar meme

autoria real pouco autenticável. Por conta disso, utilizamos um efeito de desfoque de imagem que não permite identificação nem de nomes nem de fotos de perfis. De qualquer modo, tudo foi publicado em rede social e disponível a quem quiser ler os comentários, em domínio público. 
é a "viralização", isto é, se tornar compartilhado por um grande número de pessoas. Além disso, possui, em geral, teor humorístico. Feito em redes sociais, esse compartilhamento é rápido. No recorte de material que aqui nos propomos a analisar, não é possível saber quem criou o meme em questão (imagem 3), já que não há identificação visível na imagem. No entanto, o material foi compartilhado de forma a ser utilizado como "arma" contra os apoiadores de Jair Bolsonaro, visto que, sarcasticamente e de forma caricatural, reúne vários argumentos (ou melhor, contra-argumentos) a que os apoiadores do candidato Bolsonaro recorrem, tais como "não foi bem o que ele quis dizer", "mas e o PT?" (referindo-se ao Partido dos Trabalhadores), "ele estava brincando", "foi editado", "esse vídeo aí é antigo", "esse [insira qualquer jornal aqui] é esquerdista”, "é fake news", "tiraram essa frase do contexto original" e "a urna é manipulada". Os argumentos, dessa maneira, são organizados no formato do bingo.

O bingo tradicionalmente é um jogo em que cada participante recebe uma cartela com números e, a cada número sorteado, os jogadores precisam conferir se o número dito consta em suas cartelas. Se constar, o participante marca o número. O jogo é ganho pelo jogador que primeiro completar toda a cartela, ou uma fileira na diagonal, vertical ou horizontal a depender das regras estabelecidas pelos participantes.

No primeiro uso do meme que apresentamos (imagem 3), uma casa do bingo é marcada: "foi editado", referente à alegação do interactante 2 de que houve manipulação dos vídeos para que o candidato fosse desfavorecido na opinião pública. Na sequência (imagem 4), outro usuário (interactante 3) responde ao meme:

Imagem 4: resposta ao Bingonario

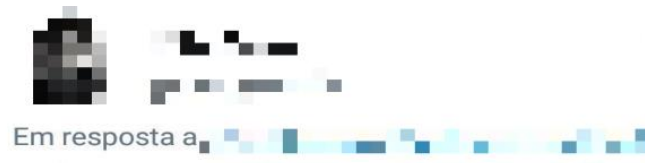

Fake news não existem, o PT é honesto, ninguém pode fazer brincadeiras, as pessoas não podem mudar de ideia, ninguém faz montagens tirando frases do contexto e a urna é tão segura que outros países mais avançados que o Brasil não a usam, ta certo 19:43 06 out 18 . Twitter Web Client

17 Retweets 241 Curtidas 
Fonte: printscreen da rede social Twitter.

Esse interactante replica com uma série de afirmações, claramente fazendo alusão ao Bingonario, embora os argumentos sejam irônicos. Entre eles, estão: "fake news não existem”, “o PT é honesto", "ninguém pode fazer brincadeiras", "as pessoas não podem mudar de ideia", "ninguém faz montagens tirando frases do contexto" e "a urna é tão segura que outros países mais avançados que o Brasil não a usam”. A ironia pode ser verificada a partir do marcador conversacional "ta certo [sic]".

A isso, o interactante 1 contra-argumenta (imagem 5):

Imagem 5: segunda utilização do Bingonario

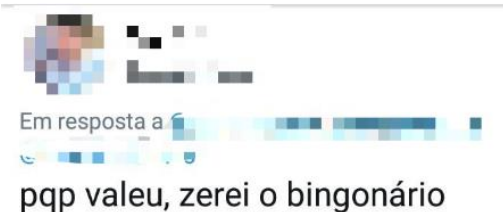

pqp valeu, zerei o bingonário

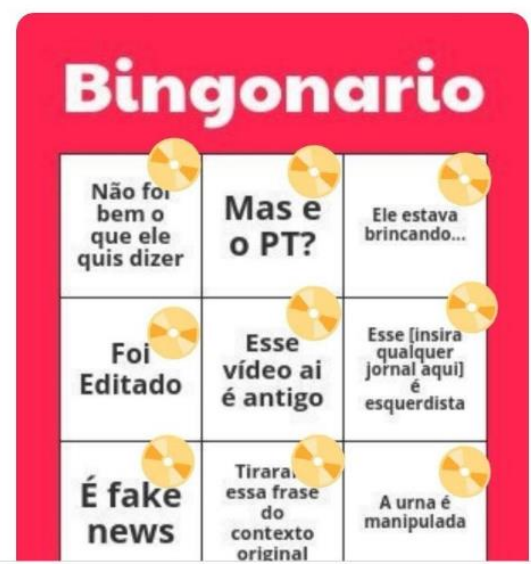

Fonte: printscreen da rede social Twitter

"Zerar" se aplica ao sentido de completar toda a cartela, a partir da junção dos argumentos do interactante 3 (imagem 4) e do interactante 2 (imagem 2). Com isso, vemos todos os quadrados marcados, indicando que o jogo foi "ganho".

Esquematizando a interação realizada na costura de troca de tweets (esquema 1), portanto, temos um protótipo da dinâmica da interação naquela teia virtual: 
Esquema 1: constituição da teia interacional

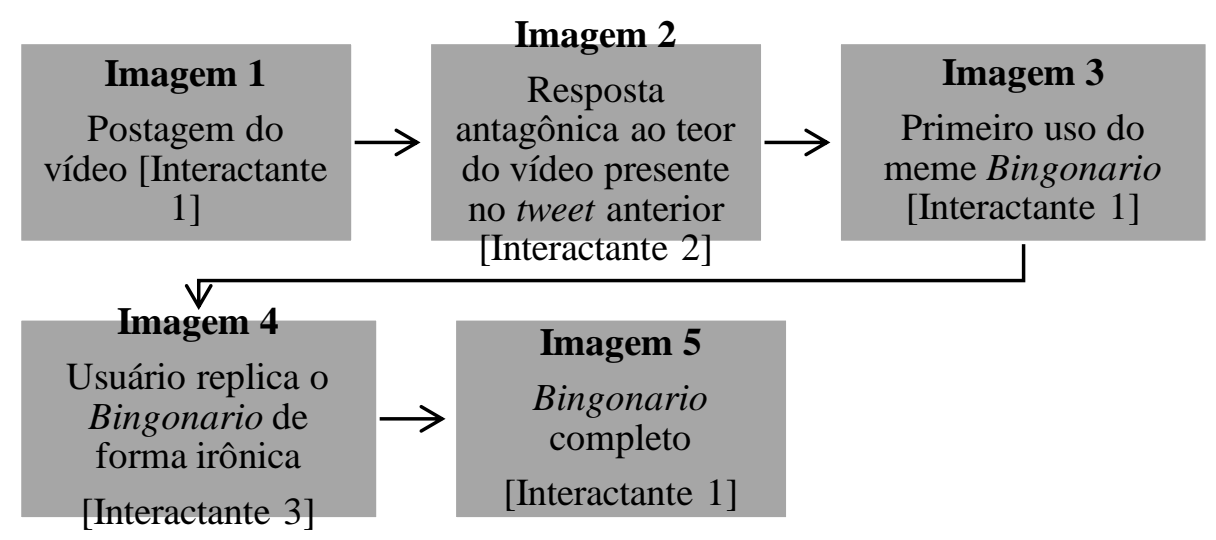

Fonte: elaborado pelos autores.

A partir da descrição da forma de interação entre os usuários do Twitter, em relação ao meme (imagem 3), propomos, na seção seguinte, analisar o papel do meme neste episódio argumentativo, o Bingonario, levando em consideração seu aspecto humorístico. Inserindo a pesquisa sob a ótica do modelo dialogal, será necessário, ainda, verificar a presença (ou não) da estase argumentativa, para cumprirmos o objetivo da análise aqui proposta.

\section{A formação da estase e o simulacro de argumentação}

As eleições à presidência de 2018 desencadearam discussões de âmbito político nas redes sociais. A polarização entre seguidores dos presidenciáveis marcou as eleições daquele ano. Os principais nomes da arena política tinham posicionamentos claros, assim como um arsenal de argumentos para utilizar contra os oponentes, e o humor foi, muitas vezes, utilizado como arma naquele contexto repleto de dissensões de viés político, muitas delas surgidas nas redes sociais. Neste sentido, o ser humano está permeado por situações humorísticas e na internet não poderia ser diferente. Devido à facilidade de circulação de materiais e ao acesso cada vez mais facilitado, é comum que as pessoas utilizem esse meio para veicular conteúdos humorísticos.

Como dissemos na apresentação deste artigo, a interação exposta anteriormente será analisada sob a ótica do modelo dialogal. Nesse sentido, procuraremos observar qual é o papel do meme naquela interação, a partir da análise acerca da presença ou ausência da estase, do conflito. 
O diálogo se inicia com a publicação do vídeo (imagem 1), que desencadeia uma série de comentários - tanto contra quanto a favor do candidato, como vimos. Para esta análise, levando em conta a interação, primordial para a análise na teoria dialogal, foram escolhidos os comentários que possuíam ambas posições para examinar o que parece ser um conflito de opiniões.

É importante ressaltar o meio em que essa interação se encontra e suas nuances. A internet está longe de ser uma "terra sem leis", já que crimes cibernéticos possuem, muitas vezes, punições rigorosas ${ }^{8}$. No entanto, possui leis próprias, moldadas por milhões de internautas ao redor do mundo. Uma de suas características é a informalidade. É possível escrever por abreviações e emoticons e até cometer escorregões em relação à gramática normativa sem que haja um estranhamento por isso. As redes representam variantes de uma língua com vida e personalidade próprias, o que é normal, à ótica da evolução linguística. Por conta disso, Crystal (2001) afirma que a internet foi mais uma revolução dos modos sociais e linguísticos do que propriamente uma revolução tecnológica.

Por ser uma revolução dos modos sociais e linguísticos, é interessante analisar as teias argumentativas que se desenvolvem no ambiente virtual. Nesta pesquisa, utilizamos o modelo dialogal (PLANTIN, 2016) para destacar a interação e o embate de opiniões opostas, denominado estase. Assim, para investigar a função do meme no episódio argumentativo apresentado anteriormente, será necessário, em primeiro lugar, verificar a presença da estase.

A estase se forma gradativamente em uma interação. Primeiramente, surge a dúvida, a primeira centelha que pode ou não gerar uma questão argumentativa, isto é, o ponto de discordância entre os interactantes (PLANTIN, 2016; GRÁCIO, 2013). Formase, assim, um conflito, a estase argumentativa.

Podemos ver isso se repetir duas vezes no corpus apresentado anteriormente. $\mathrm{Na}$ primeira situação, o interactante 1 (imagem 1) assegura a má postura do candidato por meio de um vídeo. Em seguida, o interactante 2 (imagem 2) contra-argumenta com a ideia de que a mídia seria manipulada para que opositores pudessem descredibilizá-la. A partir

\footnotetext{
8 Vide Lei dos Crimes Cibernéticos, ou Lei Carolina Dieckmann, que criminaliza a invasão de computadores para a divulgação de dados pessoais. A pena consiste em pagamento de multa e três meses a um ano de prisão.
} 
dessa questão argumentativa, em que um interactante discorda dos dizeres do outro, forma-se a primeira estase do corpus selecionado.

$\mathrm{Na}$ perspectiva dialogal, a argumentação é uma interação problematizante orientada por uma questão (GRÁCIO, 2013). No episódio argumentativo, há uma interação a partir de determinado problema (imagem 1) e a questão até então está explícita (a acusação de que o vídeo seria editado), configurando, ali, o início da estase argumentativa. Porém, a estase é ceifada a partir do surgimento do Bingonario (imagem 3) que, aparentemente, constrange o adversário (interactante 2) a ponto de ele não refutar o conteúdo do meme. Assim, o conflito, que denominamos estase, não se estabelece definitivamente, conforme a interação cessa.

No entanto, em seguida, um novo oponente surge (imagem 4/interactante 3), ironizando o meme. A definição mais comum de ironia é a de que o que o falante diz é diferente do que ele quer significar, ou seja, ele diz o contrário do que quer dizer. Conforme Orlandi (2012), a ironia se constitui a partir do locutor, do ouvinte e do texto. Essa é a tríade da composição da ironia e, sendo assim, depende da relação dos três. Logo, podemos dizer que a fala do interactante 3 é irônica, dado que ele retoma os lugarescomuns do Bingonario, contra-argumentando ao dizer o contrário do que ele quer expressar. Tomando como exemplo algumas transcrições do Bingonario ("é fake news", "mas e o PT?" e "Ele estava brincando..."), podemos visualizar o teor irônico da intervenção do interactante 3 ao afirmar que "fake news não existem", "o PT é honesto" e "ninguém pode fazer brincadeiras". Ao final, ele utiliza o marcador conversacional "ta certo [sic]", demonstrando a sua posição política contrária à do interactante 1 e, mais do que isso, comprovando a veracidade dos lugares-comuns presentes no meme, já que ele utilizou - de forma inversa, como ironia - todos os contra-argumentos comumente ditos pelos apoiadores do então candidato à presidência Jair Bolsonaro.

Logo, como consequência do primeiro uso do Bingonario (imagem 3), uma nova questão argumentativa (PLANTIN, 2016) é colocada em jogo e a estase é novamente delineada, já que o interactante 3 apresenta um posicionamento contrário ao do interactante 1. Porém, em vez de a interação argumentativa prosseguir com, talvez, uma réplica do interactante 1 utilizando outros argumentos, há uma última utilização do meme (imagem 5), demarcando o encerramento da interação - não há, naquele momento, contra- 
argumentação tampouco dos interactantes 2 e 3 como de quaisquer outros interactantes que pudessem integrar a discussão.

Desse modo, em esquema, temos:

Esquema 2: A estase na interação na rede social Twitter

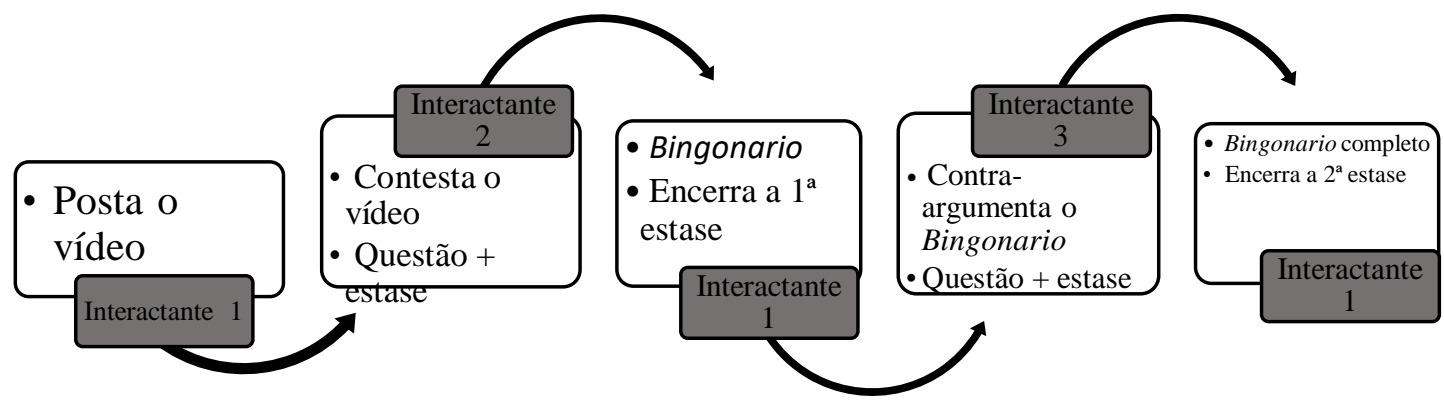

Fonte: elaborado pelos autores

À vista disso, é possível apresentarmos algumas respostas à problemática desta pesquisa que se questionou se na interação que ora apresentamos haveria ou não estase. Como dissemos, a estase é entendida como o conflito de posicionamentos contrários. Esses posicionamentos são ligados a diferentes doxai (valores), pontos de vista moldados de acordo com a vivência de cada participante da interação (GRÁCIO, 2013). Assim, vemos que o interactante 1 é contra o candidato do PSL, Jair Bolsonaro, e os interactantes 2 e 3 seriam possíveis eleitores do candidato, pois o defendem.

Além disso, conforme o modelo dialogal, o argumento seria o produto da argumentação em interações surgidas a partir de uma problemática (questão argumentativa), opondo visões contrárias. Somente a partir daí surgiria a estase. Nesse sentido, tal modelo teórico não analisa o argumento de forma a lhe garantir um peso, um valor, mas seu objetivo é precipuamente visualizar como um argumento é construído ao longo de uma interação (PLANTIN, 2016). No texto que apresentamos acima, a estase ocorre, já que há uma visível oposição de pontos de vista e eles se materializam por meio de argumentos. Portanto, enquanto o interactante 1 condena o posicionamento do candidato, os interactantes 2 e 3 o defendem e, nesse confronto de pontos de vista 
antagônicos, vem à tona a estase, como mostramos em detalhes, sobretudo no Esquema 2 .

Porém, conforme a progressão interativa ocorre, de repente algo ceifa a continuidade da argumentação: o meme! Como mostramos, a partir da utilização do meme, pudemos observar a suspensão da argumentação, apesar de ali termos constatado o surgimento da estase. Desse momento em diante (interposição do meme por um internauta) podem-se notar argumentos inconclusos neutralizados, via meme, por um conteúdo humorístico, que serve, claro, para fazer rir (dependendo da doxa na qual se insere o interlocutor) e, mais do que isso, para ridicularizar o oponente.

Pode-se dizer que os gêneros textuais sofreram e sofrem profundas alterações no ambiente virtual (MARCUSCHI, 2008). Nesse bojo, há criação de outros gêneros, tais como o meme, que, como já destacado, é um conteúdo de humor, veiculado, normalmente, pela internet, de forma rápida por meio de compartilhamento pelo maior número de usuários. O Bingonario (presente nas imagens 3 e 5) é um meme por ser um conteúdo "viral", compartilhável rapidamente pela internet. É nesse sentido, pois, que o meme é uma imbricação de recortes de informação com humor.

Imagem 6: Bingonario

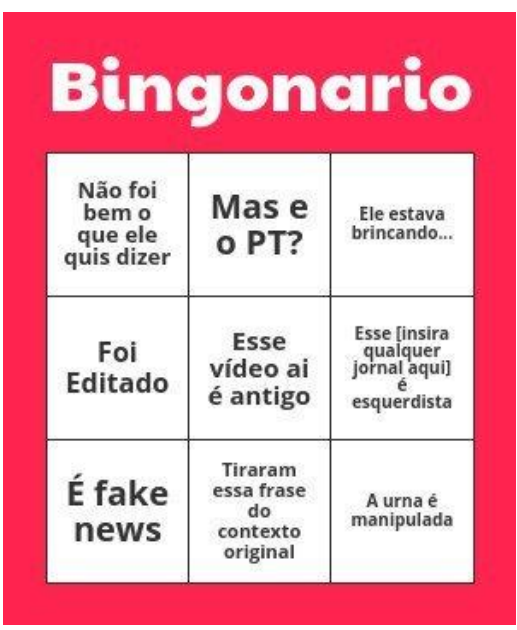

Fonte: rede social Twitter.

O formato, primeiramente, faz com que o leitor do texto se recorde do jogo bingo. E esse formato incomum talvez seja um fator cômico, dependendo do posicionamento de quem lê - eleitor ou não eleitor do então candidato Jair Bolsonaro. Para o não eleitor, o 
conteúdo é cômico. Deve-se frisar, contudo, que a interpretação do texto ocorrerá se o leitor estiver atento às notícias políticas do momento e se estiver acompanhando o debate dos candidatos e eleitores dos dois posicionamentos. Se estiver, saberá o assunto tratado e, assim, conhecerá os argumentos usualmente utilizados pelos apoiadores do candidato, que estão inseridos no Bingonario.

Os argumentos "prontos", utilizados independentemente de um contexto específico, são chamados de lugares-comuns ou clichês, frases prontas que não trazem um conteúdo novo. Geralmente, os lugares-comuns possuem conotação negativa (GRÁCIO, 2013). Dessa forma, os argumentos destacados no meme são clichês, muito repetidos, de forma que não apenas caracterizam os defensores de Jair Bolsonaro como os "caricaturizam", ou seja, torna-os caricatos, o que gera a comicidade dos argumentos dos eleitores daquele candidato.

O humor, antes de o compreendermos como um recurso argumentativo, é um recurso político. Segundo Bergson (1983), a comicidade é um instrumento punitivo, para que o alvo se sinta intimidado, humilhado. De acordo com Santos Junior (2017), há uma posição hierárquica em situações humorísticas envolvendo lados opostos: os superiores, quem humilha; e os inferiores, de quem se ri. O Bingonario seria, consequentemente, uma forma de humilhar os apoiadores do candidato Jair Bolsonaro. Dessa forma, podemos pensar no Bingonario como uma forma de o interactante 1 ridicularizar quem dele discorde, neutralizando, via meme, a continuidade da argumentação, visto que os interactantes 2 e 3 não contra-argumentam após a utilização do meme pelo interactante 1 .

Santos Junior (2017) aponta para a utilização do humor em uma argumentação. De acordo com os filósofos, o humor deveria ser utilizado para atingir determinado fim, e não em todos os momentos nem na conclusão. O cômico, assim, deveria ser "dosado", e não resumir toda a interação argumentativa. $\mathrm{O}$ meme, no episódio argumentativo analisado, resumiu, assim, toda a interação em comicidade. Não há, ali, a intenção de argumentar consonante ao ato de interação. Há, ao contrário, um recurso de ridicularização do oponente. Seria um caso de lacração? A ver.

Desse modo, podemos pensar, à vista do modelo dialogal, que interações virtuais como essa não são argumentações de fato, isto é, espaços de negociação, de interação, em que uma argumentação é tecida por meio de argumentos bem fundamentados. Na ótica dialogal, é necessário haver cooperação entre as partes para que a argumentação progrida, 
fato que não é perceptível nessa interação em especial, visto que o meme é utilizado para ridicularizar o oponente ou, tão-somente, interromper o fluxo da conversa e fim de papo.

Podemos ainda observar que, após o uso do meme na interação, não há resposta dos interactantes 2 e 3 . Assim, interações como a apresentada poderiam ser vistas como simulacros de argumentação, isto é, aparentam ser interações argumentativas, moldadas com a aparição de problemáticas e respostas sequenciais, mas a argumentação não progride, é ceifada, e a estase é neutralizada, fazendo com que o fio da argumentação se torne inconcluso. Sendo assim, repetimos, o meme se apresenta como uma obstrução da estase e serve, principalmente, para “desarmar", para ridicularizar o oponente. O simulacro de argumentação seria, então, uma argumentação falaciosa, no sentido primeiro de falácia, ou seja, algo que aparenta ser e não é. No caso desta análise, aparenta ser uma argumentação, mas, verdadeiramente, não é, embora apresente estase, como mostramos em detalhes.

\section{Considerações finais}

Concluída a análise, pudemos atingir o objetivo deste artigo, o qual diz respeito à função do meme no episódio argumentativo analisado. Com esta pesquisa, pretendemos, por meio da análise da costura argumentativa na interação na rede social Twitter, verificar o papel desempenhado pelo meme em uma discussão política.

Como foi mencionado, as eleições à presidência de 2018 foram polarizadas, gerando, assim, inúmeras manifestações a favor e contra os candidatos e seus apoiadores. As redes sociais foram o principal palco dessas manifestações. Por possuir potencial de análise rico para a pesquisa na área argumentativa, a escolha do corpus se orientou nesse sentido. Além de estar em consonância com o modelo dialogal de Christian Plantin, que destaca a importância da interação em episódios argumentativos, como mostramos detalhadamente.

Para analisar o uso do meme no corpus apresentado, foi necessário, em um primeiro momento, verificar a existência ou inexistência da estase, do conflito. A estase é a materialização da questão argumentativa, das ideias opostas. Desse modo, havendo a demonstração de opiniões contrárias, por consequência, há estase. Com isso, pudemos averiguar a presença da estase, embora, na interação, sua presença fosse subitamente ceifada pelo meme apresentado. Apoiados em Bergson, consideramos o humor mais do 
que um simples conteúdo para provocar riso. O humor é uma arma e, em argumentações, pode ser utilizado como um recurso político, determinando uma posição hierárquica quem ridiculariza e a quem se ridiculariza.

O meme serviu, assim, como um neutralizador da argumentação e, consequentemente, da estase argumentativa. Na íntegra, o episódio argumentativo pode ser denominado um simulacro de argumentação, uma simulação da interação argumentativa. A interrupção da estase demarca, assim, o término da interação. Doxai opostas não mais se enfrentam. O marcador disso é o meme, o qual, aparentemente, ridiculariza a ponto de os demais interactantes desistirem do debate. Com os simulacros argumentativos, a internet se torna um ringue, em que, para seus usuários, o importante é "sair por cima", vencer os oponentes, mesmo que para isso se utilizem do humor como munição.

\section{Referências}

ALVES, Lara. Você conhece o Chico? Cachorro destrói cama e vídeo viraliza; veja. 2019. Disponível em: <https://www.otempo.com.br/interessa/bizarrices/voce-conhece-ochico-cachorro-destroi-cama-e-video-viraliza-veja-1.2211442>. Acesso em: 12 jan. 2020.

AMOSSY, Ruth. Apologia da polêmica. Trad. Rosalice Botelho Wakin Souza Pinto [et al]. São Paulo: Contexto, 2017.

BERGSON, Henri. Ensaio sobre a significação do cômico. 2. ed. Trad. Nathanael C. Caixeiro. Zahar Editores, Rio de Janeiro, 1983.

CARMELINO, Ana Cristina. Humor: uma abordagem retórica e argumentativa. Revista do Programa de Pós-Graduação em Letras da Universidade de Passo Fundo. v. 8. n. 2. p. 40-56. jul./dez. 2012.

CRYSTAL, D. Language and the Internet. Cambridge: Cambridge University Press, 2001.

DAMASCENO-MORAIS, Rubens. Dialogando com a perspectiva dialogal da argumentação. In: PIRIS, Eduardo Lopes; RODRIGUES, Maria das Graças Soares (Org.). Estudos sobre argumentação no Brasil hoje: modelos teóricos e analíticos. Natal, RN: EDUFRN, 2020. E-book. p. 143-169.

DAMASCENO-MORAIS, Rubens. PALESTRA (3): Rubens Damasceno-Morais Modelo dialogal 1. 2019. (22m15s). Disponível em: <https://www.youtube.com/watch?v=aT0arBEl06c\&t=704s $>$. Acesso em: 25 jan. 2021.

DAWKINS, R. Memes: os novos replicadores. In: DAWKINS, R. O gene egoísta. Trad. Rejane Ribeiro. São Paulo: Companhia das Letras, 2017. p. 193-205. 
FERREIRA, Dina Maria Martins; VASCONCELOS, Marco Antônio. Discurso de memes: (Des)memetizando ideologia antifeminista. Bakhtiniana, São Paulo, v. 14, n. 2, p. 44-61, abril/junho 2019.

GONÇALVES, Joanicy Maria Brito. Humor, política e redes sociais na internet: uma mistura que deu certo. e-Com, Belo Horizonte, v. 12, 2019.

GRÁCIO, R. Vocabulário Crítico de Argumentação. Coimbra: Grácio Editor, 2013.

MARCUSCHI, L. Gêneros textuais no ensino de língua. In: MARCUSCHI, L. Produção textual, análise de gêneros e compreensão. São Paulo: Parábola, 2008.

ORLANDI, E. Destruição e Construção do Sentido: Um Estudo da Ironia. Revista WEBdiscursividade, Edição 09, jan.-mai. 2012. Disponível em: <http://www.discursividade.cepad.net.br/EDICOES/09/Arquivos/eniorlandi.pdf>. Acesso em: 23 de outubro de 2019.

PLANTIN, Christian. Dictionary of Argumentation: An Introduction to Argumentation Studies. Lyon: ENS Éditions, 2016.

SANTOS JUNIOR, Jaime Fernando dos. O cômico como estratégia retórica no debate político. Faces da História, Assis-SP, v.4, no 2, p. 218-233, jun.-dez., 2017.

TRAVAGLIA, Luiz Carlos. Uma introdução ao estudo do humor pela lingüística. DELTA - Revista de Documentação de Estudos em Lingüística Teórica e Aplicada, São Paulo, v. 6, n. 1, p. 55-82, 1990.

TSAKONA, Villy; POPA, Diana Elena. Humour in politics and the politics of humour: an introduction. In: TSAKONA, Villy; POPA, Diana Elena (Org.). Studies in political humour: in between political critique and public entertainment. Philadelphia: John Benjamins Publishing, 2011.p. 1-32. 